\title{
Detection of Conjugative Plasmid Encoded Ampicillin and Tetracycline Resistant in Klebsiella pneumonia
}

\author{
Dogan Ozdemir ${ }^{1}$, Shako Hassan ${ }^{1} \&$ Duran Kala ${ }^{1}$ \\ ${ }^{1}$ Faculty of Dentistry, Ishik University, Arbil, Iraq \\ Correspondence: Dogan Ozdemir, Faculty of Dentistry, Ishik University, Arbil, Iraq. Tel: 964-750-636-9587. \\ E-mail: ozdemirtalha@gmail.com
}

Received: September 8, 2012

doi:10.5539/ijb.v5n2p28

\author{
Accepted: December 24, 2012 Online Published: March 4, 2013 \\ URL: http://dx.doi.org/10.5539/ijb.v5n2p28
}

\begin{abstract}
Klebsiella pneumonia were isolated and identified on the basis of morphology, growth, and biochemical characteristics. All the isolates offered different resistance patterns against antibiotics including Ampicillin, Cefotaxime, Erythromycin, tetracycline and Chloramphenicol. Transformation and conjugation techniques were used for plasmid transfer studies. The conjugation experiment showed that $\approx 51 \mathrm{kbp}$ conjugative plasmid conferring resistance to tetracycline and ampicillins were successfully transferred to the recipient cells $E$. coli MM294. The rest of the plasmid borne markers was non-conjugative/nontransferable. Conjugative plasmids carry a tremendous potential to disseminate resistance markers to distant recipient cells. The protocol is reliable enough to be used for large-scale visualization of native plasmids and we have used it to visualize and isolate DNA from hundreds of multidrug resistance plasmids.
\end{abstract}

Keywords: Klebsiella pneumonia, plasmid, multidrug resistance, conjugative plasmids

\section{Introduction}

Bacteria belonging to genus Klebsiella frequently cause human nosocomial infections. In particular, the medically most important Klebsiella species, Klebsiella pneumoniae, account for significant proportion of hospital acquired urinary tract infection, pneumonia, septicemia, and soft tissue infection (Emori \& Gaynes, 1993). K. pneumoniae is frequently found in many different geographical locations, with beta-lactamase resistance becoming a growing problem (Matthew, 1979).

The wide spread use of antimicrobial agents in the treatment of infections in the tropics has led to serious problems of antimicrobial resistance. The emergence and spread of antibiotic resistance in bacteria of medical importance imposes serious constraint on the option available for treatment of many infections (Nikadio, 1998). (Li \& Lim, 2000) mentioned that in the last 10 years, the extensive spread of multiple antibiotic-resistant Klebsiella pneumoniae strains, especially the extended-spectrum beta lactamase producing strains (ESBLs), has become a major threat to the ever-increasing number of immune compromised patients; the ESBLs are usually plasmid mediated (R plasmid) offer resistance to antibiotics and are transmissible from one cell to another by direct cell contact (conjugation).

Conjugative plasmids are thought to be responsible for the rapid spread of beta-lactamase resistance in Gram-negative bacteria (Reed, 1981).

Another factor believed to be involved in the increasing of resistance is the presence of transposon carried beta-lactamase, which leads to spread of beta-lactamase resistance among different plasmids (Sander \& Sander, 1992).

This study included an attempt to:

(1) Antibiotic susceptibility test for K. pneumoniae isolated from Teaching hospital and biology department.

(2) Transferring about $60 \mathrm{Kbp}$ conjugative plasmid to E. coli MM294

\section{Literature Review}

\subsection{Genus Klebsiella}

Klebsiella is straight rod, 0.3-1.0 $\mu \mathrm{m}$ in diameter and 0.6-6.0 $\mu \mathrm{m}$ in length, arranged singly in pairs, or in short chains. Cells are capsulated, Gram negative non motile, facultatively anaerobic, chemoorgano-trophic, having 
both a respiratory and fermentative type of metabolism. Optimal temperature is $37^{\circ} \mathrm{C}$. D-Glucose and other carbohydrates are catabolized with the production of acids and gas. Oxidase negative and catalese positive Indole, methyl red, Voges-proskauer, and Simmons citrate reactions vary among species. Several species hydrolyze urea grow on $\mathrm{KCN}$. $\mathrm{H}_{2} \mathrm{~S}$ is not produced .Reduces Nitrates. Most species ferment all tested carbohydrates except dulcitol and erythritol (Holt et al., 1994).

\subsection{Genetic Contents of K. pneumoniae}

The genetic material in bacteria is carried on double - stranded circular DNA molecule, folded multiple times to fit inside the cell and attached to the plasma membrane. This DNA molecule is generally referred to as the bacterial genome. It contains all the information for controlling the development and metabolic activities important for bacterial survival. The typical bacterial genome is a single chromosome, about $1.100 \mathrm{~mm}$, containing up to $4000 \mathrm{kbp}$ of DNA, folded into a tight mass, often less than $0.2 \mathrm{~mm}$ in diameter, and complexed with small amounts of protein and RNA (Cano et al., 1986).

Numerous bacteria contain, in addition to their genome, one or multiple copies of small self-replicating pieces of circular double stranded DNA, called plasmids. The molecular mass of the plasmid is between $1.5-300 \mathrm{MD}$ and it contains $1-30 \mathrm{kbp}$. Small plasmids contain only a few genes, while the larger one may consist hundreds of genes (up to 300 genes) (Jawetz et al., 1995). After division of the bacterial cell, all the following generations will have the same plasmid profile, belonging to a same bacterial clone. The transfer of the plasmid between cells can be accomplished by conjugation or transformation. Genetic information, required for transfer by conjugation, is supplied by the so-called tra-genes, carried on the other side, by self-transmissible plasmids. Plasmids transferred by conjugation, continue to multiply once they have entered the new host. Some of their genes can even be transferred to the chromosome as transposons leading to the acquisition of functions not normally encoded in the chromosome (Zajcek, 1994).

In general, the plasmid's genetic information is not necessary for the survival of the cell. However, they can supply the bacterial cells with new features, important for their survival in new and extraordinary conditions. Depending on what kind of a function the plasmid determinates, there are different types of plasmids: F-plasmids - which contain genes for production of F-pills, Col-plasmids - determine a production of bacteriocines, Vir-plasmids - closely related with the pathogen potential of different bacteria, Ent-plasmids - with genes for exotoxine production determination. There are plasmids that often carry genetic information that makes the bacterium resistant to certain antibiotics and heavy metals, able to synthesize or break down unusual compounds, resistant to ultraviolet light or able to produce bacteriocines and toxins. For example, antibiotic resistance genes may be carried on plasmids (so called R-plasmids) and the plasmids are the structures that code for enzymes that acetylate adenylate or phosphorylate various antibiotics (Cano et al., 1986).

Nowadays, nosocomial infections are an important cause of morbidity and mortality. Predominant pathogens are Pseudomonas aeruginosa, Staphylococcus aureus, Enterococcus, E. coli, K. pneumoniae and Candida spp (Haur et al., 1996). Among Gram-negative bacilli, which comprise the majority of nosocomial pathogens, $K$. pneumoniae, has considerably big role (Horan et al., 1988).

The genus Klebsiella, as a member of the family Enterobacteriaceae, encloses two medical significant species: $K$. pneumoniae (with four variations-K. pneumoniae var. aerogenes, var. pneumoniae, var. rhinoscleromatis and var. ozaenae) and K. oxytoca. K. pneumoniae is a member of the normal intestinal microflora and it can be found in minority as a part of the microflora of the upper respiratory tract. It becomes pathogenic only when will reach tissues outside of its normal flora site. K. pneumoniae often colonizes the skin and mucosae of hospitalized patients in intensive care units, with risk of invasive infection and septicemia. The colonization of the host's gastrointestinal tract by multi-antibiotic resistant $K$. pneumoniae strains is thought to be an essential step in nosocomial $K$. pneumoniae infections. The most frequent sites of clinically important infections are the urinary, billiary and lower respiratory tract, but it can also play a role in septicaemia, meningitis and osteomyelitis (Seldon et al., 1971).

\subsection{Antimicrobial Resistance}

Antimicrobial resistance is defined as "a property of bacteria that confers the capacity to inactivate or exclude antibiotics, or a mechanism that blocks the inhibitory or killing effects of antibiotics, leading to survival despite exposure to antimicrobials" (Ingli et al., 1994.)

\subsection{Plasmids}

Plasmids form a vital part of the bacterial genome and can constitute up to $10 \%$ or more of the DNA in a bacterial cell. Plasmids can transfer by a variety of means including conjugation and transformation. Most bacteria are capable of becoming hosts to a large array of different plasmids commonly found in other strains, 
other species or even other genera. Plasmids thus represent a large genetic resource for diversity and adaptation of bacteria (Thorsted et al., 1998).

Resistance to $\beta$-lactam antibiotics is mediated by plasmid with variations of the SHV and TEM-type $\beta$-lactamase genes (Barthelemy et al., 1988). Most of these plasmid-mediated $\beta$-lactamases from Klebsiella species have been grouped as TEM or SHV-related $\beta$-lactamases (Horii et al., 1993). Furthermore, K. pneumoniae is the species in which plasmid-encoded ESBLs are commonly reported (Jacoby \& Medeiros, 1991). The threat of an increase in multiple resistances to antibiotics in K. pneumoniae is shown by French et al. (1996) with hyper production of SHV-5 $\beta$-lactamase. Nevertheless, it has been reported that the majority of ESBL-producing isolates of $E$. coli and Klebsiella species are also resistant to gentamicin and other aminoglycosides (Jones et al., 1994). All these multiple resistance genes are usually carried on large transferable plasmids. Large plasmid profiles from $K$. pneumoniae associated with multiple resistances have been documented in Europe (Montgomerie et al., 1993; Reed et al., 1995; Marchese et al., 1996), United States (Wallace et al., 1995; Schiappa et al. 1996) and Asia (Wang et al., 1995). Prodinger et al. (1996) mentioned that there was R plasmid with $80 \mathrm{kbp}$ responsible for conferring resistance to SHV-5 in K. pneumoniae isolates. This R plasmid transfer between species of family Enterobacteriaceae in nosocomial out break stresses the need plasmid typing, especially because SHV-5 beta-lactamase seems to regionally spread predominately via plasmid transfer. Shannan et al. (1998) showed that 70 to $160 \mathrm{kbp}$ of conjugative plasmid responsible for encoding the SHV-4, TEM-15 and TEM-16 in K.pneumoniae. (Li \& Lim, 2001) showed novel large plasmid (97 145 Kbp) carrying multiple $\beta$-lactamase resistance genes isolated from K. pneumoniae strain.

\subsection{Materials and Substances}

3.1.1 Apparatus and Tools

\subsubsection{Materials}

3.1.3 Plasmids and Bacterial Strain

Table 1. Plasmids and strains that used in experiment

\begin{tabular}{|c|c|c|}
\hline $\begin{array}{l}\text { plasmids and } \\
\text { bacterial strains }\end{array}$ & Phenotype \&Genotype & Source \\
\hline $\begin{array}{l}\text { E.coli GMP4176 } \\
(p R 751)\end{array}$ & $\begin{array}{l}\text { hsd } R^{-}, \text {hsd } M, r e c A^{-}, l e u^{-} \\
\text {pro, lac, gat, } \mathrm{Sm}^{\mathrm{r}}\end{array}$ & $\begin{array}{l}\text { Institute of genetic engineering and biotechnology } \\
\text { for postgraduate studies Baghdad university }\end{array}$ \\
\hline E. coli MM294 & $\begin{array}{l}\text { hsd } R^{-}, \text {hsd } M^{+}, \text {edn AI, pro, } \\
\text { thi, Rif' }\end{array}$ & $\begin{array}{l}\text { Biology department } \\
\text { University of Sulaimani }\end{array}$ \\
\hline
\end{tabular}

$\boldsymbol{h s d}^{-}$: lack of restriction system;

hsd $\boldsymbol{M}^{+}$: presence of modification system;

$\boldsymbol{h s} \boldsymbol{d} \boldsymbol{M}$ : lack of modification system;

$\operatorname{rec} A^{-}$: lack of recombination system;

end AI: lack of end nuclease activity;

gal: have no ability to ferment galactose;

tra : lack of tra genes;

Inc P: incompatibility $\mathbf{P}$ group;

pro $^{-}$, lue ${ }^{-}$and thi' (proline, luecine, and thymine respectively): need proline, luecine and thymine in their growth media;

Tp: trimethoprim;

r: Resistance. 


\subsubsection{Culture Media and Solutions}

\subsubsection{Buffers and Solutions}

a. Antibiotic Solution

Antibiotic solutions were prepared according to (Al-zaaq, 1987; Baron \& finegold, 1990). The antibiotic solution stocks sterilized by Millipore filter 0.22 , and stored at $4^{\circ} \mathrm{C}$.

Table 2. concentration of antibiotics that used in the culture media

\begin{tabular}{llll}
\hline Antibiotic & $\begin{array}{l}\text { Final concentration in culture } \\
\text { media }(\mu \mathrm{g} / \mathrm{ml})\end{array}$ & $\begin{array}{l}\text { Solvent used to dissolve } \\
\text { antibiotic }\end{array}$ & $\begin{array}{l}\text { Manufacture } \\
\text { Company }\end{array}$ \\
\hline Ampicillin( $\mathrm{Ap})$ & 150 & Distilled water & Oxoid(England) \\
Rifampcin (Rif) & 100 & Aceton & Sigma(Germany) \\
Tetracycline (TC) & 20 & Ethanol alcohol/water 50\% & Oxoid \\
Kanamycin (Km) & 50 & Distilled water & Sigma \\
Streptomycin (Sm) & 100 & Distilled water & Oxoid \\
Chloramphenicol (Cm) & 50 & Aceton & Oxoid \\
Amoxillin (Ax) & 50 & Distilled water & Sigma \\
Trimethoprim (Tp) & 50 & Aceton & Sigma \\
Cefotaxime (Ctx) & 50 & Distilled water & Sigma \\
\hline
\end{tabular}

\section{b. Saline EDTA}

The buffer was prepared by dissolving 0.15 mol of sodium chloride, 0.1 mol of EDTA in distilled water and the $\mathrm{pH}$ was adjusted to 8 with $1 \mathrm{~N} \mathrm{NaOH}$. Then volume of solution was adjusted to one liter with distilled water. The solution was sterilized by autoclave (Murmur, 1961).

c. Lysozyme Solution

This solution was prepared freshly by dissolving $10 \mathrm{mg}$ of Lysozyme in $200 \mu \mathrm{l}$ STET buffer (Sambrook et al., 1989).

\section{d. SDS Solution}

This solution was prepared by dissolving $50 \mathrm{mmol}$ of Tris-base in $70 \mathrm{ml}$ of distilled water then the $\mathrm{pH}$ was adjusted to 12.6 with $1.2 \mathrm{ml}$ of $2 \mathrm{~N} \mathrm{NaOH}$. The volume was completed to $100 \mathrm{ml}$ with distilled water. The solution was sterilized by filtration and stored at $4^{\circ} \mathrm{C}$ (Kado \& Liu, 1989).

e. TE Buffer

The buffer was prepared by dissolving $0.01 \mathrm{~mol}$ of Tris-base and $0.001 \mathrm{~mol}$ of EDTA in distilled water then the $\mathrm{pH}$ adjusted to 8 . The volume of the solution was completed to one liter with distilled water and the solution was sterilized by autoclave (Sambrook et al., 1989).

\section{f. STE Buffer}

The buffer was prepared by dissolving $0.050 \mathrm{M}$ of Tris-base, $0.005 \mathrm{M}$ of EDTA and $0.050 \mathrm{M}$ of $\mathrm{NaCl}$ in distilled water then the $\mathrm{pH}$ adjusted to 8 . The volume of the solution was completed to one liter with distilled water and the solution was sterilized by autoclave (Sambrook et al., 1989).

\section{g. EDTA-Sodium Acetate}

The Solution was prepared by dissolving $3 \mathrm{~mol}$ of sodium acetate, $0.001 \mathrm{~mol}$ of EDTA in distilled water. The $\mathrm{pH}$ was adjusted to 7 with acetic acid, and then the volume of the solution was completed to one liter with distilled water. The solution was sterilized by autoclave (Sambrook et al., 19819).

h. Chloroform- Isoamyl Alcohol Mixture

This solution was prepared in a ratio of $24: 1$ and stored in bottle at $4^{\circ} \mathrm{C}$ (Sambrook et al., 1989). 


\section{i. Phenol Solution}

The solution was prepared by melting the phenol at of $68^{\circ} \mathrm{C}$, and then $0.1 \%$ of antioxidant 8 -hydroxyquinoline was added to it, un equal volume of buffer solution of $0.5 \mathrm{~mol}$ Tris- $\mathrm{HCl}$ at $\mathrm{pH} 8$ was added to the mixture and mixed well by mechanical vortex and then the solution left to set at room temperature. The upper aqueous layer was separated from the lower layer. The upper layer was discard by pasture pipette and then an equal volume of 0.1 molar Tris- $\mathrm{HCl} \mathrm{pH} 8$ was added to the phenol and this process was repeated until the $\mathrm{pH}$ of phenol become more than 7.8. The phenol solution was stored under thin layer of 0.1 molar Tris solution in a dark bottle at $4^{\circ} \mathrm{C}$ (Sambrook et al., 1989).

j. Phenol: Chloroform: Isoamyl Alcohol Mixture

Phenol, chloroform, isoamyl alcohol was mixed together at ratio of 25:24:1 and was stored under a layer of 0.1 molar Tris- $\mathrm{HCl}$ solution ( $\mathrm{pH} 8$ ) in a dark bottle at $4^{\circ} \mathrm{C}$ (Sambrook et al., 1989).

\section{k. TBE Buffer}

The solution was prepared by dissolving 0.089 mole of Tris-base, 0.089 mole of boric acid and 0.002 mole $\mathrm{Na}_{2}$-EDTA in distilled water. The $\mathrm{pH}$ of the solution was adjusted to 8 with $1 \mathrm{~N} \mathrm{NaOH}$ and the volume of solution was completed to one liter with distilled water. The solution was sterilized by autoclave (Sambrook et al., 1989).

1. Ethedium Bromide Dye

The dye solution was prepared by dissolving $0.5 \mathrm{mg}$ of Ethedium bromide in $10 \mathrm{ml}$ distilled water, and the solution was stored in dark bottle at room temperature (Sambrook et al., 1981).

m. Extraction Solution:

Solution I was prepared by mixing $50 \mathrm{mM}$ glucose, $25 \mathrm{mM}$ Tris-Cl (pH 8) and $10 \mathrm{mM}$ EDTA (pH 8). The solution was prepared in batches of $\sim 100 \mathrm{ml}$ then the solution was sterilized by autoclave and stored at $4^{\circ} \mathrm{C}$.

Solution II was prepared by mixing $0.2 \mathrm{~N} \mathrm{NaOH}$ (freshly diluted from $10 \mathrm{~N}$ stocks) and 1\% SDS. Solution III (3M Sodium acetate) $\mathrm{pH} 4.8$ : It was prepared by mixing $60 \mathrm{ml}$ of $5 \mathrm{M}$ potassium acetate, $11.5 \mathrm{ml}$ glacial acetic acid and $28.5 \mathrm{ml}$ of distilled water (Sambrook et al., 1989).

n. Normal Saline

It was prepared by dissolving 0.15 moles from sodium chloride and 0.1 mole of $\mathrm{KH}_{2} \mathrm{PO}_{4}$ in distilled water, the $\mathrm{pH}$ was adjusted to 7.2 by adding $1 \mathrm{~N} \mathrm{NaOH}$. Then the volume was completed to one liter by adding distilled water, and then sterilized by autoclave.

\subsubsection{Culture Media}

A. Ready Culture Media

Table 3. Ready culture media used during experiments

\begin{tabular}{ll}
\hline Culture media & Manufacture company \\
\hline Eosin methylene blue agar(EMB) & (Difco U.S.A). \\
MacConKey agar & (Difco-U.S.A). \\
Muller-Hinton agar & (Difco-U.S.A). \\
Nutrient agar & (Mast diagnostics U.K). \\
Nutrient broth & (Mast diagnostics U.K). \\
\hline
\end{tabular}

The following media were prepared as recommended by the manufacturing company and autoclaved.

B. Prepared Culture Media

\section{a. SOC Liquid Medium}

It was prepared by dissolving $2 \mathrm{gm}$ of trypton, $0.5 \mathrm{gm}$ yeast extract, and 0.005 gm sodium chloride in $90 \mathrm{ml}$ distilled water and then $1 \mathrm{ml}$ of $0.25 \mathrm{M}$ of potassium chloride was added, the $\mathrm{pH}$ of the solution was adjusted to 7 and the volume completed to $100 \mathrm{ml}$. Before using, $0.5 \mathrm{ml}$ of $2 \mathrm{M}$ magnesium chloride, and $1 \mathrm{ml}$ of 0.25 
molar of glucose previously been sterilized by filtration was added when the medium used as solid culture, $2 \%$ of agar would be added (Sambrook et al., 1989).

b. Luria broth

It was prepared by dissolving 10 gm of trypton, 5 gm yeast extract, and $10 \mathrm{gm}$ sodium chloride in $950 \mathrm{ml}$ distilled water. The $\mathrm{pH}$ of medium was adjusted to 7 then the volume was completed to one liter, and then sterilized by autoclave (Sambrook et al., 1981).

\subsection{Methods}

\subsubsection{Sterilization}

\subsubsection{Dry sterilization}

Glasswares were sterilized using oven instrument at $180^{\circ} \mathrm{C}$ for two hr.

\subsubsection{Autoclaving}

All the media, solutions and used in this work were autoclaved at $121^{\circ} \mathrm{C}$ for $15 \mathrm{~min}$.

\subsection{2 $\mathrm{pH}$ of Culture Media}

The hydrogen ion concentration $(\mathrm{pH})$ for all culture media was adjusted to $(7.2-7.4)$ using $\mathrm{pH}$ meter.

\subsubsection{Identification of K. pneumoniae}

\subsubsection{Microscopical Examination (Gram Staining Film)}

Smears were prepared by taken a small amount of isolated colony from a bacterial culture on a glass slide by mixing a colony of tested bacterium with a drop of distilled water, stained with Gram stain and examined using oil immersion objective lens under 100X power.

\subsubsection{Cultural Characteristics}

The morphological characteristics of isolated colonies were carefully studied with the aid of a lens 10X lens.

Depending on above two criteria the cultures were primarily classified as pure or mixed cultures.

\subsubsection{Antibiotic Resistance}

A. Antibiotic sensitivity test (Antibiotic susceptibility test by disk-diffusion method (Kirby Bauer test)

A single colony of bacterial strain was transferred to a fresh test tube containing $5 \mathrm{ml}$ Brain-Heart infusion broth then incubated for 24 hours at $37^{\circ} \mathrm{C}$. After that $0.1 \mathrm{ml}$ of the inoculum was transferred to a Muller-Hinton agar plate, streaked by a sterile straight wire all over the surface of the medium three times. After 10-15 min, antibiotic discs were plated on the medium then incubated at $37^{\circ} \mathrm{C}$ for 24 hours. After incubation the inhibition zone diameters were determined in millimeters $(\mathrm{mm})$, comparison was done with standard inhibition zone (Mahon \& Manuselis, 2000)

Table 4. Antibiotic disc used in antibiotic susceptibility test

\begin{tabular}{lll}
\hline Antibiotic disc & Concentration $(\boldsymbol{\mu g} /$ disc $)$ & Manufacture company \\
\hline Amoxicillin (Ax) & 25 & Jovet \\
Ampicillin (Amp) & 10 & Oxoid \\
Cefotaxime (CTM) & 30 & Oxoid \\
Chloramphinicol (C) & 30 & Oxoid \\
Nalidixic acid (NA) & 30 & Oxoid \\
Neomycin (N) & 30 & Oxoid \\
Novobiocin (NV) & 30 & Oxoid \\
Rifampicin (RA) & 5 & Oxoid \\
Streptomycin (S) & 10 & Oxoid \\
Tetracycline (TE) & 30 & Oxoid \\
Trimethoprim (TEM) & 5 & Oxoid \\
\hline
\end{tabular}




\section{B. Antibiotic Resistance Test in Solid Cultures Media}

The Mullar-Hinton agar was prepared and sterilized by autoclave, cooled to $50^{\circ} \mathrm{C}$. Antibiotic solution in appropriated concentration was added to the cooled culture medium, poured into sterilized Petri dish and left to solidify, then. The bacterial isolates were cultured by picking and patching method. The result were recorded by presence (+) or absence of growth (-) (Al-zaaq, 1987; Nassif et al., 1989).

\subsubsection{Detection of Presence of Plasmid DNA}

\subsubsection{Plasmid DNA Extraction}

A-Extraction of large plasmid:

Alkaline lysis method of Kado and Liu (1981) was used to extract large plasmids and the salting out method was used to prepare total DNA (Pospiech \& Neuman, 1995)

1. A single colony of bacterial isolate was incubated into LB agar plates that containing $150 \mu \mathrm{g} / \mathrm{ml}$ of ampicillin. Then the plates were incubated at $37^{\circ} \mathrm{C}$ for $24 \mathrm{hrs}$.

2. The bacterial cells were collected by sterilized loop and transfer to polypropylene tube with plastic cap containing $5 \mathrm{ml}$ of STE buffer.

3. The bacterial cells were precipitated by centrifugation at $3000 \mathrm{xg}$ for $15 \mathrm{~min}$. the supernatant was discarded and the pellet was resuspended by $5 \mathrm{ml}$ of STE buffer.

4. Aliquot of $600 \mu \mathrm{l}$ of $25 \%$ SDS solution and $120 \mu \mathrm{l}$ of proteinase $\mathrm{K}(20 \mathrm{mg} / \mathrm{ml})$ were added to the bacterial suspension and incubated in water bath at $55^{\circ} \mathrm{C}$ for $2 \mathrm{hrs}$.

5. Aliquot of $2 \mathrm{ml}$ of $5 \mathrm{M} \mathrm{NaCl}$ solution was added to the lysate, then mixed by inversion, and left to cool to $37^{\circ} \mathrm{C}$.

6. Equal volume of phenol-chloroform-isoamyl alcohol mixture $(24: 24: 1)$ was added to the lysate then mixed gently by inversion for 30 min until an emulsion formed.

7. The mixture was separate by centrifugation at $12000 \mathrm{rpm}$ for $10 \mathrm{~min}$ at $4{ }^{\circ} \mathrm{C}$. The aqueous phase was transferred by pipette to a fresh tube. (The steps 6 and 7 were repeated until no protein was visible at the interphase of the organic and aqueous phases).

8. Equal volume of chloroform was added to the aqueous phase that contains the nucleic acid and step 7 was repeated.

9. Aliquot of $0.6 \%(\mathrm{v} / \mathrm{v})$ isopropanole was added to the extract and mixed by inversion then the DNA was spooled onto a sealed pasture pipette rinsed in $70 \%$ cold ethanol then dissolved in 1-2 $\mathrm{ml} \mathrm{TE} \mathrm{buffer} \mathrm{pH}$ 8.

B- Plasmid extraction by alkaline lyses:

1. Single colony of the bacterial isolate was grown in $10 \mathrm{ml}$ of LB broth containing $50 \mathrm{mg} / \mathrm{ml}$ ampicillin and incubated at $37^{\circ} \mathrm{C}$ for $24 \mathrm{hr}$. with shaking. Bacterial cells were harvested by centrifugation at 10000 rpm for $10 \mathrm{~min}$.

2. The pellet resuspended in $10 \mathrm{ml}$ of EST/saline buffer.

3. The suspension centrifuged at $10000 \mathrm{rpm}$ for $10 \mathrm{~min}$. (the step 2, 3 repeated twice)

4. The pellet was resuspended in $0.2 \mathrm{ml}$ of solution $\mathrm{I}$, then transferred to sterile eppendorf tube and omitted for 5 minutes at room temperature.

5. Aliquot of $0.4 \mathrm{ml}$ of solution II was added to the mixture and then the eppendorf tube was gently inverted for many times and omitted in ice bath for $15 \mathrm{~min}$.

6. Aliquot of $0.3 \mathrm{ml}$ of cold solution III was added to the mixture above and the eppendorf tube was inverted for many times before putting on ice bath for $5 \mathrm{~min}$.

7. The mixture was centrifuged at $14000 \mathrm{xg}$ for $5 \mathrm{~min}$.

8. Aliquot of $0.5 \mathrm{ml}$ of the supernatant was transferred to the new sterile eppendorf, then an equal volume of phenol-chloroform-isopropanole solution was added and mixed very well then the solution objected to centrifugation as previous step.

9. The upper layer was transferred to the new sterile eppendorf, and both the middle and lower layer omitted, this step was repeated till the protein was excluded from the solution. 
10. Aliquot of $3 \mathrm{M}$ of cold sodium acetate in ratio of 0.1 volumes was added to the supernatant that contain plasmid DNA and mixed very well.

11. Double volume of cold absolute ethanol was added to the suspension and mixed gently and then left at $-10^{\circ} \mathrm{C}$ for two hr.

12. The mixture was centrifuged at $12000 \mathrm{rpm}$ for $15 \mathrm{~min}$. then the ethanol was excluded from the solution, and the pellet was washed by $70 \%$ ethanol and then centrifuged as in the previous step.

13. The eppendorf was inverted on sterile filter paper and the pellet dissolved in $50 \mu \mathrm{l}$ of TE buffer and stored at $-20^{\circ} \mathrm{C}$ (Sambrook et al., 1989):

C- Determination of DNA concentration by spectrophotometer:

Concentration of prepared DNA was estimated using spectrophotometer by applied this equation (Sambrook et al., 1989):

$$
\text { Conc. of DNA } \mu \mathrm{g} / \mathrm{ml}=\text { optical density at } 260_{\mathrm{nm}} \times \text { dilution factor } \times 50 \mu \mathrm{g} / \mathrm{ml}
$$

\subsubsection{Gel Electrophoresis}

According to method of Sambrook et al. (1989), agarose gel were prepared by dissolving 0.7 gm agarose powder in $100 \mathrm{ml}$ of $1 \mathrm{X}$ Tris-borate buffer , heated to boiling in water bath. The gel was cooled to $60{ }^{\circ} \mathrm{C}$ then $100 \mu \mathrm{l}$ of Ethedium bromide was added to final concentration of $0.5 \mu \mathrm{g} / \mathrm{ml}$ and mixed thoroughly. The edge of the a lean, dry glass plate was sealed with tape so as to form a mold and the mold set on horizontal section of the bench. The comb was placed above the plate. The gel was poured into the mold $(10 \times 20 \mathrm{~cm})$. After that the gel was allowed completely to set for 30-45 min at room temperature, the comb and surrounding former cover were removed and the gel soaked in a gel tank containing (1 X) Tris-borate buffer. $15 \mu 1$ of DNA samples were mixed with $3 \mu \mathrm{l}$ of loading buffer dye, Finally $10 \mu \mathrm{l}$ of this mixture was loaded into the wells, then the gel tank were closed by lid and electrical leads was attached $1-5 \mathrm{v} / \mathrm{cm}$ was applied for 1-2 $\mathrm{hr}$. After that the electric current turned off and removes the leads and the lid from the gel tank. The gel was examined by UV-light and photographed the gel.

\subsubsection{Bacterial Conjugation}

Day one:

1- A single colony of donor strain was inoculated in to $50 \mathrm{ml} \mathrm{LB}$ broth containing appropriated antibiotic.

2- A single colony of E. coli MM294 rif ${ }^{\mathrm{r}}$ recipient was inoculated in to $50 \mathrm{ml} \mathrm{LB}$ broth containing $100 \mu \mathrm{g} / \mathrm{ml}$ of rifampcin.

3- The cultures were incubated overnight at $37^{\circ} \mathrm{C}$ for $18 \mathrm{hr}$. with vigorous shaking or until OD $590 \approx 0.54$.

Day two: Surface mating

$1-5 \times 10^{7}$ of donor cell and $1 \times 10^{8}$ recipients were mixed in sterile eppendorf.

2- The pellet was resuspended in $50 \mu 1$ of LB and the cells were transferred to $0.22 \mu \mathrm{m}$ Millipore filter on LB agar plate.

3- The LB agar plates which contain Millipore filter were incubated at $37^{\circ} \mathrm{C}$ for $1-2 \mathrm{hr}$.

4- The cells were resuspended by placing filter in a tube containing $0.5 \mathrm{ml}$ of $0.85 \%$ saline and agitating the tube on a vortex.

5- Serial $1 / 10$ dilution was made to $10^{-8}$ of the mating mixture.

6- Aliquot of $0.1 \mathrm{ml}$ of dilution $10^{-1}$ to $10^{-6}$ was spread on LB agar containing rifampcin $(100 \mu \mathrm{l} / \mathrm{ml})$ and trimethoprim $(50 \mu \mathrm{l} / \mathrm{ml})$.

7- Aliquot of $0.1 \mathrm{ml}$ of original overnight culture of donor and recipient was spread on the same medium to determine the frequency of antibiotic resistance spontaneous mutation.

8- $0.1 \mathrm{ml}$ of dilution $10^{-6}$ and $10^{-8}$ was spread on LB agar containing rifampcin $(100 \mu \mathrm{l} / \mathrm{ml})$ to estimate the number of recipient cells in the mating.

9- All plates were incubated at $37^{\circ} \mathrm{C}$.

Control:

A- Aliquot of $0.1 \mathrm{ml}$ of donor cells was transferred to rifampcin plate. 
B- Aliquot of $0.1 \mathrm{ml}$ of recipient cell Escherichia coli MM294 rif $^{\mathrm{r}}$ were transferred to Plates containing antibiotic of donor strain.

9- All plates were incubated at $37^{\circ} \mathrm{C}$.

Day three:

The colonies that had grown on the selection plate was counted and the number of bacteria per $\mathrm{ml}$ in mating mixture exhibiting the phenotype rifampcin (total recipient) and $\mathrm{Rif}^{\mathrm{r}}, \mathrm{Tp}^{\mathrm{r}}$ (transconjugant)was calculated (O' Connell, 1984)

The frequency of conjugation was calculated as below:

$$
\text { Tranconjugant cells per Recipient cells }=\frac{\text { No. Of transconjugants cells } / \mathrm{ml}}{\text { No. of recipients cells } / \mathrm{ml}}
$$

\subsubsection{Transformation}

\subsubsection{Preparation of Competent Cells}

1- A starting culture was prepared by adding freshly isolated single colony to $5 \mathrm{ml}$ of nutrient broth medium and grown overnight at $37^{\circ} \mathrm{C}$.

2- Aliquot of $0.3 \mathrm{ml}$ of starting culture was inoculated in to $60 \mathrm{ml}$ of fresh nutrient broth medium and the cells were grown at $37^{\circ} \mathrm{C}$ for $1-2 \mathrm{hr}$.

3- The culture was chilled on ice for 5-7 minutes; cell suspension was centrifuged at $8000 \mathrm{rpm}$ for 15 min in a sterile $100 \mathrm{ml}$ glass centrifuge tube.

4- The supernatant was discarded; the pellet was resuspended in half of original culture volume, $(30 \mathrm{ml})$ of an ice-cold sterile solution of $0.1 \mathrm{M} \mathrm{CaCl}_{2}$.

5- The cell suspension was placed on ice, and then centrifuged at $8000 \mathrm{rpm}$ for $15 \mathrm{~min}$.

6- Supernatant was discarded and the pellet was resuspended in $1 \mathrm{ml}$ of ice cold $0.1 \mathrm{M} \mathrm{CaCl}_{2}\left(\mathrm{Sambrook}_{\mathrm{a}}\right.$ et al., 1989).

\subsubsection{DNA up Takes}

1- For each $200 \mu 1$ of competent cells in a transformation tube $10 \mu 1$ of a DNA solution was added and incubated on ice bath for $30 \mathrm{~min}$.

2- The competent cells were heat- shocked by placing the tube in a $42^{\circ} \mathrm{C}$ water bath for $90 \mathrm{Sec}$. and then $3 \mathrm{~min}$. at ice bath.

3- Aliquot of $800 \mu \mathrm{l}$ of pre wormed $\left(37^{\circ} \mathrm{C}\right)$ SOC medium was added to the suspension and Incubated at $37^{\circ} \mathrm{C}$ with moderate agitation for $60 \mathrm{~min}$.

4- Aliquot of $0.1 \mathrm{ml}$ cells were spread quickly and gently on selective plated, SOC agar plates by spreading.

5-The plates were incubated upside down at $37^{\circ} \mathrm{C}$ over night.

6- The transformants colonies were calculated as below:

$$
\text { Transformant frequency }=\frac{\text { No. of transformants cells } / \text { Concentration of DNA }(\mu \mathrm{g} / \mathrm{ml})}{\text { Competent cells }}
$$

7- Co-transfer for transformant cells were made on different plates containing different type of antibiotics (Sambrook et al., 1989).

\section{Results and Discussion}

4.1 Re-identification of K.pneumoniae No.10 Isolate K. pneumoniae No. 10 had previously been isolated by (Hamad, 2006), which re-identified by using api 20 E. as in Figure 1. 


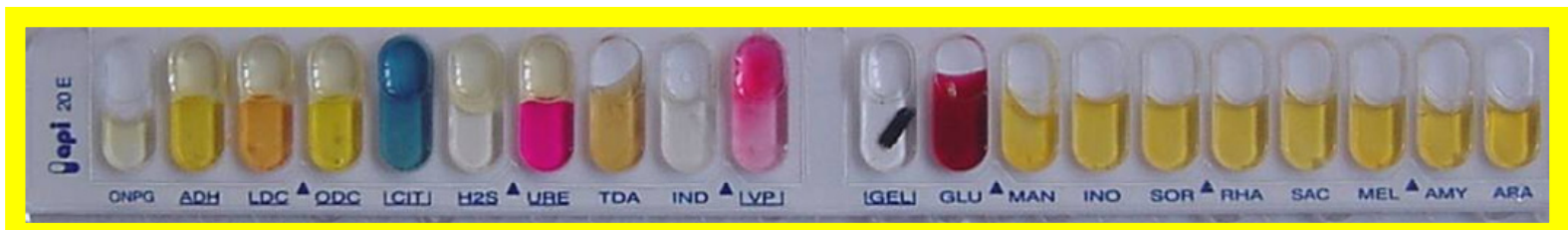

Klebsiella pneumoniae (5215773) [\%97.7] accuracy of diagnosis.

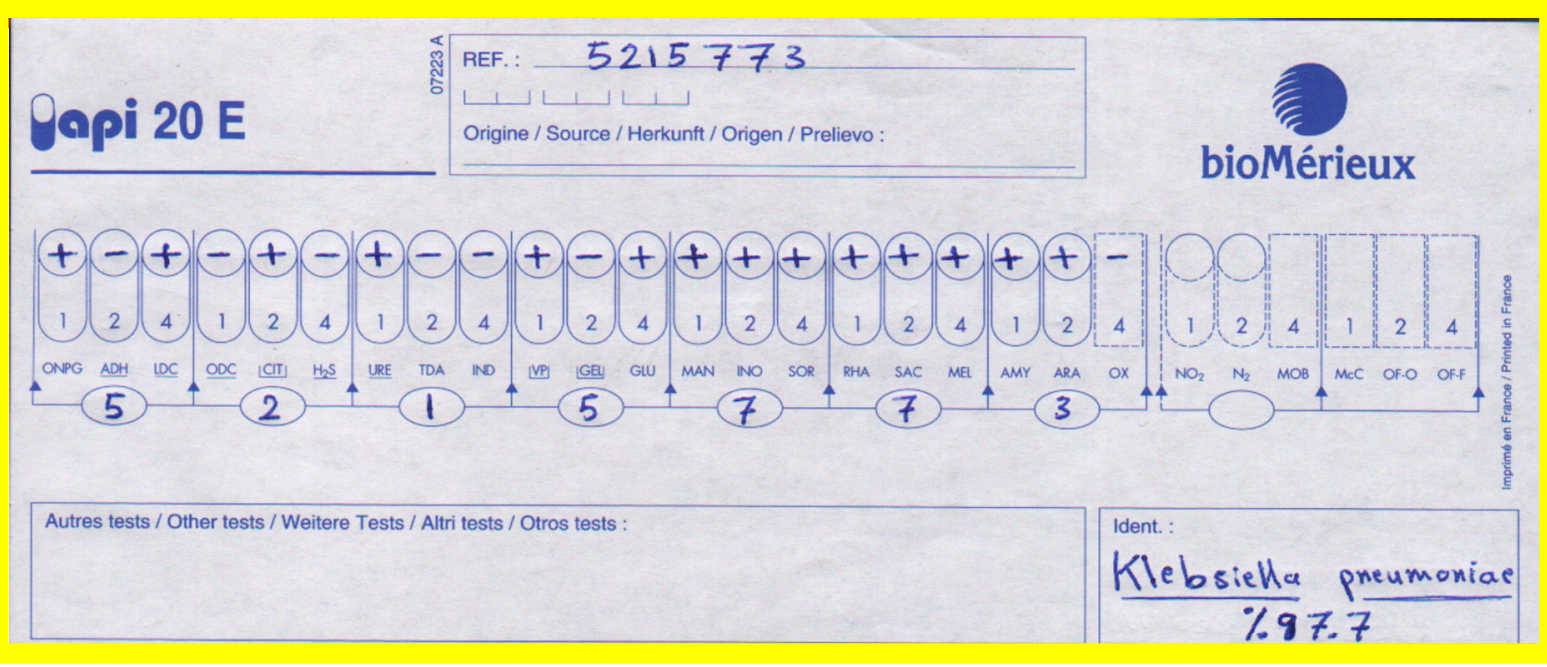

Figure 1. Re- Identification of K. pneumoniae No.10 Using api 20E

Table 5. The resistance of Klebsiella pneumoniae isolates to antibiotics

Antibiotic Sensitivity Tests

No. of Isolates Source of Isolation Ap AK Ax Car Cip Cm CTX Ery Gm Lin N Pi Rif Sm Tc Tri

\begin{tabular}{|c|c|c|c|c|c|c|c|c|c|c|c|c|c|c|c|c|c|}
\hline Klebsiella pneumonia & $\begin{array}{l}\text { Clinical caulture } \\
\text { from upper } \\
\text { respiriatory system }\end{array}$ & + & + & + & + & - & - & - & + & + & + & + & - & - & + & + & + \\
\hline E. coli & $\begin{array}{l}\text { Baghdad genetic } \\
\text { eng.institute }\end{array}$ & - & - & - & - & - & - & - & - & + & - & - & - & + & - & - & + \\
\hline
\end{tabular}

Ap: ampicillin, Ak: amikacin, Ax: amoxicillin, Car: carbencillin, Cip: ciprofloxacin, Cm: chloramphenicol, Ctx: cefotaxime, Ery: erythromycin, Gm: gentamycin, Lin: lincomycin, N: neomycin, Pi: penicillin, Rif: rifampicin, Sm: streptomycin, Tc: tetracycline, and tri: trimethoprim.

* The symbols (+): Resistance to Antibiotics, (-): Sensitive to Antibiotics, and (I): intermediate. 
Table 6. The transformation frequency and number of transformant colonies among four strains of Klebsiella pneumoniae isolates.

\begin{tabular}{|c|c|c|c|c|c|c|c|c|c|c|c|c|c|c|c|}
\hline \multirow{2}{*}{$\begin{array}{l}\text { Klebsiella } \\
\text { pneumoniae } \\
\text { isolates and } \\
\text { Transformant } \\
\text { cells }\end{array}$} & \multicolumn{15}{|c|}{ Growth on M. H. agar containing antibiotics in $(\mu \mathrm{g} / \mathrm{ml})$} \\
\hline & Ap & Ak & Ax & Car & Cip & $\mathrm{Cm}$ & Ctx & Ery & $\mathrm{Gm}$ & Lin & $\mathrm{Pi}$ & Rif & $\mathrm{Sm}$ & Tc & Tri \\
\hline $\begin{array}{l}\text { Klebsiella } \\
\text { pneumoniae }\end{array}$ & + & + & + & + & - & - & - & + & + & + & - & - & + & + & + \\
\hline E. coli & + & - & - & - & - & - & - & - & + & - & - & + & - & + & + \\
\hline
\end{tabular}

\subsection{Antibiotic Susceptibility Test for K. pneumoniae No. 10 Isolat}

The isolate was resistant to most antibiotics including ampicillin, tetracycline, streptomycin, kanamycin, trimethoprim, Chloramphenicol, and nalidixic acid (Table 5).

The wide spread use of $\beta$-lactamase groups of antibiotic against bacterial infection and continued mismanaged selective pressure has contributed toward the emergence of extended spectrum- $\beta$-lactamase resistance bacteria (Cohen, 1992). It demonstrated that $\beta$-lactamase which was associated with high level ampicillin resistance in K. pneumoniae strains are mainly produced by large plasmid pK1 (Livermore, 1995).

Philippon et al. (1989) indicated that one large plasmid encoding multidrug resistance genes usually carry one $\beta$-lactamase encoded gene, which is probably a mutant of the TEM-1 gene to code for enzyme capable of hydrolyzing the extended -spectrum $\beta$-lactam.

\subsection{Study of Plasmid Contents in K. pneumoniae No. 10 Isolate}

Upon mating of rifampicin resistant E. coli MM294 with K. pneumoniae No. 10 ampicillin, tetracycline-resistant Tranconjugant $\left(\mathrm{TR}_{1}\right)$ was selected at frequency of $7.25 \times 10^{-4}$ per recipient. The $55 \mathrm{~kb}$ conjugative plasmid, which confers ampicillin, tetracycline resistance, was successfully transferred to $E$. coli MM294 by conjugation.

Peterson et al. (1982) referred that when two or more plasmids reside in the same cell, they may coexist stably without affecting one another, or may interact in some way. One possible interaction is physical exchange of segments of DNA.

Prodinger et al. (1996) mentioned that there was R plasmid with $80 \mathrm{kbp}$ responsible for conferring resistance to SHV-5 in $K$. pneumoniae isolates. This $\mathrm{R}$ plasmid transfer between species of family Enterobacteriaceae in nosocomial outbreak stresses the need plasmid typing, especially because SHV-5 beta-lactamase seems to regionally spread predominately via plasmid transfer.

Shannan et al. (1998) showed that 70 to $160 \mathrm{kbp}$ of conjugative plasmid responsible for encoding the SHV-4, TEM-15 and TEM-16 in K. pneumoniae. Li and Lim (2001) showed novel large plasmid (97 145Kbp) carrying multiple $\beta$ -lactamase resistance genes isolated from K. pneumoniae strain. 


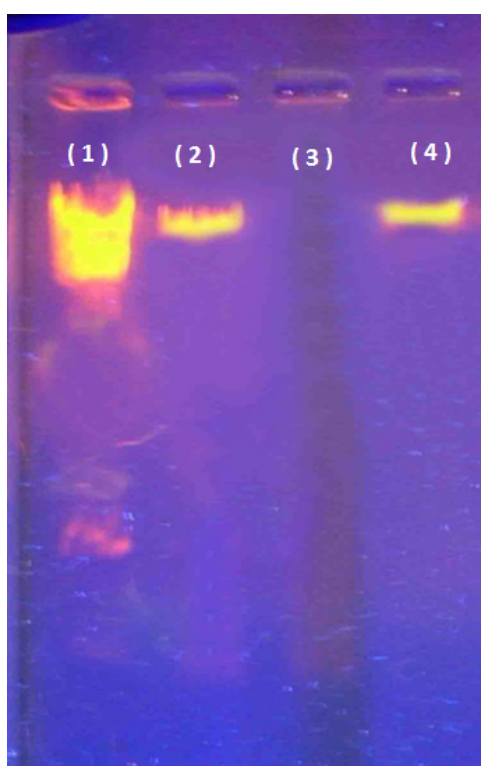

Figure 2. The plasmid profile of the transconjugant bacterial cells of E. coli MM294

From left to right:

Lane 1: DNA content of Klebsiella pneumoniae isolate;

Lane 2: DNA content of transconjugant E. coli;

Lane 3: DNA content of standard plasmidless strain E. coli MM294;

Lane 4: R751 plasmid (51 Kbp).

\section{Conclusions}

The detection of transposon encoding an extended-spectrum $\beta$-lactamase (ampicillin) on large plasmid $\mathrm{pKpI}$ in $K$. pneumoniae isolate No.10 from patients suffer from upper respiratory inflammation in hospital where large quantities of extended-spectrum $\beta$-lactam antibiotic are used, raises concern for the increased spread of resistance to this group of antibiotics.

It has been concluded that gene responsible for conferring resistance to ampicillin reside in a 5.000 bp mobile DNA segment or transposon which have ability to translocated themselves by both Intramolecular and intermolecular transposition.

We deduced that transposon which conferring ampicillin resistances in K.pneumoniae I and transposed via co-integrate formation is belonging to $\operatorname{Tn} 3$ family.

Translocation of ampicillin transposon accompanied with disturb of regular or structural genes function due to insertion inactivation of this transposon to those genes.

Transposition of transposon that carry ampicillin determinant was more in $30^{\circ} \mathrm{C}$ than $37^{\circ} \mathrm{C}$, consequently the total change in antibiotic susceptibility pattern for K.pneumoniae I that grew at $30^{\circ} \mathrm{C}$ was more than Klebsiella pneumoniae I that grew at $37^{\circ} \mathrm{C}$.

\section{Recommendation}

This study advises to determine nucleotide sequence and G-C ratio of this transposon which confers ampcillin resistance to K. pneumoniae in order to confirm whether our transposon is similar to Tn3 family or not. We also recommend further analyzing of this transposon by using suitable DNA probes of the Tn3 family transposon family and hybridized them with our transposon for further identification. Finally we advise for further Identification of the type of beta-lactamase that expressed by our transposon by isoelectric focusing and determine the type of beta-lactamase.

\section{References}

Al-Jlawi, R. O. (2000). Genetic Study on the Mucoviscid Phenotype of Klebsiella pneumoniae (Ph. D. thesis). University of Baghdad. 
Al-Zaaq, A. (1987). Cloing and Molecular Characterization of Hemolysine and $\beta$-Glycosidase Genes of Citrobacter freundii (Ph. D. thesis). University of Queezland.

Arlet, G., Rouveau, M., Casin, I., Bouvet, P. J., Lagrange, P. H., \& Philippon, A. (1994). Molecular Epidemiology of Klebsiella pneumoniae Strains that Produce SHV-4 beta-lactamase and which were isolated in 14 Fr. J. Clin. Microbiol., 32, 2553-2558.

Arlet, G., Sanson-le Pors, M. J., Rouveau, M., Fournier, G., Marie, O., Schlemmer, B., \& Philippon, A. (1990). Outbreak of Nosocomial Infections due to Klebsiella pneumoniae Producing SHV-4 beta-lactamase. J. Clin. Microbiol. and Infect. Dis., 9, 797-803. http://dx.doi.org/ 10.1029/JD090iD06p10529

Baron, E. J., \& Finegold, S. M. (1990). Bailly and Scott's diagnostic microbiology.8th edition. The C. V. Mosby company. Missour, 171-186.

Barthèlèmy, M., Peduzz, J., Benyaghlane, Y., \& Labia, R. (1988). Single Amino Acid Substitution between SHV-5 $\beta$-lactamase and Cefotaxime-hydrolyzing SHV-2 Enzyme. FEBS Letter, 231, 217-220.

Barthelemy, M., Peduzzi, J., \& Labia, R. (1988). Complete amino acid sequence of p453-plasmid-mediated PIT-2 beta-lactamase (SHV-1). Biochemic. J., 251, 73-79.

Bascomb, S., Lapage, S. P., Willcox, W. R., \& Curtis, M. A. (1971). Numerical Classification of Tribe Klebsiella. J. Gen. Microbiol., 66, 279-295. http://dx.doi.org/ 10.1099/jmm.0.024059-0

Bauernfeind, A., Rosenthal, E., Eberlein, E., Holley, M., \& Schweighart, S. (1993). Spread of Klebsiella pneumoniae Producing SHV-5 beta-lactamase among Hospitalized Patients. Infect., 21, 18-22.

Bétermier, M., Poquet, I., Alazard, R., \& Chandler, M. (1992). Involvement of Escherichia coli FIS Protein in Maintenance of Bacteriophage Mu lysogeny by the Repressor: Control of early transcription and inhibition of transposition. J. Bacteriol., 175, 3798-3811.

Blumberg, P. M., \& Strominger, J. L. (1974). Interaction of Penicillin with the Bacterial cell: Penicillin-binding Proteins and Penicillin-sensitive Enzymes. Bacteriol. Rev., 38, 291-335. http://dx.doi.org/10.1111/j.1432-1033.1994.00597.x

Bonafede, M., \& Louis, B. R. (1997). Emerging Antibiotic Resistance. J. lab. Clinical Medical Biology, 130(6), 558-566.

Bradford, P. A. (2001). Extended-spectrum $\beta$-lactamase in the 21st century: Characterization, Epidemiology, and Detection of this Important Resistance Threat. Clin. Microbiol. Rev., 14(5), 933-951.

Calos, M. P., \& Miller, L. H. (1980). Transposon Element. Cell, 20, 579-595.

Cano, J. R., Jaime, C., \& Colome, C. (1986). Microbiol (pp. 203-240). West publishing company.

Capy, P., Gasperi, G., Biemont, C., \& Bazin, C. (2000). Stress and Transposable Elements: Coevolution or Useful Parasites? Selfish DNA. Nat., 85, 101-106.

Chakraborty, P. (1999). A text Book of Microbiology (p. 281). New Central Book Agency (P) LTD.

Chang, A. C. Y., \& Cohen, S. N. (1978). J. Bacteriol., 134, 1141-1142. http://dx.doi.org/ 10.1128/IAI.05851-11

Chen, F. J., \& Lo, H. J. (2003). Molecular Mechanisms of Fluoroquinolone Resistance. J. Microbiol. Immunol. Infect., 36, 1-9. http://dx.doi.org/ 10.1371/journal.pone.0034609

Cohen, M. L., \& Auxe R. V. (1992). Drug Resistant Salmonella in the United State: An Epidemiol. Sci, 234, 964-970.

Corinaldesi, C., Roberto, D., \& Antonio, D. (2004). Simultaneous Recovery Extracellular and Intracellular DNA Suitable for Molecular Studies from Marine Sediments. Appl. Env. Microbiol., 71(1), 46-50.

Cornelis, G. (1979). Transposition of Tn951 (Tn Lac) and Cointegrate Formation are Thermosensitive Processes. J. Microbiol., 117, 243-247

Davies, C. J., \& Hutchison, C. A. (1995). Insertion Site Specificity of the Transposon Tn3. Nuc. Aci. Res., 23, 507-514.

Davies, J. (1994). Inactivation of Antibiotics and the Dissemination of Resistance Genes. Sci., 264, 375-382.

DE Lacruz, F., \& Grinsted, D. (1982). Genetic and Molecular Characterization of Tn21, A multiple Resistance Transposon from R100. J. Biol., 151, 222-228. http://dx.doi.org/ 10.1128/AAC.00982-07

Di-Martino, P., Sirot, D., Joly, B., Rich, C., \& Darfeuille- Michaud, A. (1997). Relationship between Adhesion to 
Intestinal Caco-2 Cells and Multidrug Resistance in Klebsiella pneumoniae Clinical Isolates. J. Clin. Microbiol., 35, 1499-1503. http://dx.doi.org/ 10.1099/jmm.0.47380-0

Domenico, P., Johanson, W., \& Straus, D. (1982). Reduction of Capsular Polysaccharide Production in Klebsiella pneumoniae by Sodium Salicylate. Infect. Immun., 57(12), 3778-3782.

Donta , S. T., Peduzz, P., Cross A. S., Sadoff, J., Haakenson, C., Cryz, S. J., ... Slagle, D. (1996). Immunoprophylaxis against Klebsiella and Pseudomonas aeruginosa Infection. The Federal Hyperimmune Immunoglobulin Trial study Group. J. Infect. Dis., 174, 537-543.

Doolittle, W. F., \& Sapienza, C. (1980). Selfish Genes, the phenotype paradigm and genome evol. Nat., 284, 601-603.

Emori, T. G., \& Gaynes R. P. (1993). An overview of Nosocomial Infection, including the Role of the Microbiology Laboratory. Clin. Microbiol. Rev., 6, 428-442.

Ewing, W. H. (1986). Identification of Enterobacteriaceae (4th ed.). Elsevier, Netherlands.

Fedoroff, N. V. (1985). Genes. In McGraw-Hill Yearbook of Science and Technology (pp 197-199). NY: Pub McGraw-Hill Inc.

Ferragut, C., Izard, D., Gavini, F., Kersters, K., Deley, J., \& Leclerc, H. (1983). Klebsiella trevisanii: A new Species from Water and Soil. Int. J. Syst. Bacteriol., 33, 133-142. http://dx.doi.org/ 10.1155/2010/134086

French, G. L., Shannon, K. P., \& Simmons, N. (1996). Hospital Outbreak of Klebsiella pneumoniae Resistant to Broad-spectrum Cephalosporins and Beta-lactam-beta-lactamase Inhibitor Combinations by Hyperproduction of SHV-5 beta-lactamase. J. Clin. Microbiol., 34, 358-363.

Gary, P. A., Biery, M. C., Bainton, R. J., \& Craig, N. L. (1996). Multiple DNA Processing Reactions Underlie Tn7 Transposition. J. Mol. Biol., 257, 301-316. http://dx.doi.org/ 10.1038/nchembio.534

Gavini, F., Izard, D., Grimont, P. A., Beji, A., Ageron, E., \& Leclerc. (1986). Priority of Klebsiella planticola Bagley, Seidler, and Brenner 1982 over Klebsiella trevisanii. Ferragut, Izard, Gavini, Kersters, Deley, and lecrec.1983. Int. J. Syst. Bacteriol., 36, 486-488.

George, A. M., Hall, R. M., \& Stokes, H. W. (1995). Multidrug Resistance in Klebsiella pneumoniae: A novel Gene, ram A, Confers a multidrug Resistance Phenotype in Escherichia coli. Microbiol., 141, 1909-1920.

Goryshin, I. Y., \& Reznikoff, W. S. (1998). J. Biol. $\quad$ Chem., $273, \quad 7367$. http://dx.doi.org/10.1007/978-1-61779-197-0_4_1

Grindley, N. D. F., \& Reed, R. R. (1985). Transpositional Recombination in Prokaryotes. Annu. Rev. of Biochem., $54,863-896$

Gross, R. J. (1992). Pneumonia. In G. Green Wood, D. David, S. Richard, C. Slack, \& F. John (Eds.), Churchill living stone (p. 338). Urinary tract infection; Opportunistic Infection: Pathogenesis, Immunity, Laboratory diagnosis and Control.

Gutmann, L., Williamson, R., Moreau, R., Kitzis, M. D., Collatz, E., Acar, J. F., \& Goldstain, F. W. (1985). Cross Resistance to Nalidixic Acid, Trimethoprim and Chloramphenicol Associated with Alterations in the outer Membrane Protein of Klebsiella, Enterobacter, and Serratia. J. Infect. Dis., 151, 501-507.

Hedges, R. W., \& Jacob, A. E. (1974). Transposition of Ampicillin Resistance from RP4 to Other Replicons. Mol Gen Genet, 132, 31-40.

Hefforn, F., Sublett, R. R., Hedges, W. A., Jacob, E., \& Falkow. S. (1975). Origin of the TEM Beta lactamase Gene found on Plasmid. J. Bacteriol., 122, 250-256. http://dx.doi.org/ 10.1038/nm1008-1053

Heffron, F. (1983). Tn3 and its Relatives. In J. A. Shapiro (Ed.), Mobile Genetic Elements (pp. 223-260). New York: Academic Press.

Heritage, J., Peter, M. H., Neil, T., \& Lan, L. (1992). Transposition of Gene Encoding a TEM-12 Extended- $\beta$ -lactamase. Antimicrob. and Chemother, 36(9), 1981-1986.

Hettle, S. J. H. (1995). Effects of Temperature on the Transposition of Tn1 - Analysis of Transposition Products, Initial Project Handout.

Holt, J. G., Noel, R. K., Peter, H. A. S., James, T. S., \& Stanley, T. W. (1994). Determinative Bacteriology (9th ed.) Lippincott Williams \& Wilkins. Page181.

Hõrak, R., \& Kivisaar, M. (2001). Regulation of Transposition of Tn4652: Involvement of Pseudomonas putida 
Integration Host Factor and Transposon-encoded Inhibitor TnpC. Manuscript.

Horan, T., Culver, D., Jarvis, W., Emori, G., Banerjee, S., Martone, W., \& Thornsberry, C. (1988). Pathogens Causing Nosocomial Infection. Antimicrobic News I, 5, 65-67.

Horii, T., Arakawa, Y., Ohta, M., Ichiyama, S., Wacharotayankun, R., \& Kato, N. (1993). Plasmid-mediated AmpC-type Beta-lactamase Isolated from Klebsiella pneumoniae Confers Resistance to Broad-spectrum Beta-lactams, including moxalactam. Antimicrob. and Chemother, 37, 984-990. http://dx.doi.org/10.1128/AAC.37.5.984

Inglis, T. J., Kumarasinghe, G., Chow, C., \& Liew, H. Y. (1994). Multiple Antibiotic Resistances in Klebsiella spp. \& other Enterobacteriaceae Isolated in Singapore. Singapore Medi. J., 35, 602-604.

Institute of Medicine (IOM). (1989). Human Health Risks with Subtherapeutic Use of Penicillin or Tetracyclines in Animal Feed. Committee on human health risk assessment on using subtherapeutic antibiotics in animal feeds. National Academy Press, Washington, D. C.

Jacoby, G. A., \& Medeiros, A. A. (1991). More Extended Spectrum beta-Lactamase. Antimicrob. and Chemother., 35, 1697-170.

Jawetz, E., Melnick, J. L., \& Adelberg, E. A. (1995). Medical Microbiology (pp. 86-104). Alange Medical Book.

Jones, R. N., Kehrberg, E. N., Erwin, M. E., \& Anderson, S. C. (1994). Prevalence of Important Pathogens and Antimicrobial Activity of Parental Drugs at Numerous Medical Centers in the United States, I. Study on the threat of emerging resistance: real or perceived? Fluoroquinolone Resistance Surveillance Group. Diagnostic Microbiol and Infect. Dis., 19, 203-215.

Kado, C., \& Liu, S. T. (1981). Rapid Procedure for Detection and Isolation of Large and Small Plasmids. $J$. Bacteriol., 145(3), 1365-1373.http://dx.doi.org/ 10.1128/AEM.02890-10

Kidwell, M. G., \& Lisch, D. R. (2001). Perspective: Transposable Elements, Parasitic DNA, and Genome Evolution. Evolution Int. J. Org. Evol., 55, 1-24. http://dx.doi.org/ 10.1371/journal.pone.0027513.g001

Kleckner, N. (1981). Transposable Elements in Prokaryotes. Ann. Rev. Genet., 15, 341-404

Kleckner, N. (1990). Regulation of Transposition in Bacteria. Annu. Rev. Cell Biol., 6, 297-327.

Knothe, H., Shah, P., Krcmery, V., Antal, M., \& Mitsuhashi, S. (1983). Transferable Resistance to Cefotaxime, Cefoxitin, Cefamandole and Cefuroxime in Clinical Isolates of Klebsiella pneumoniae and Serratia marcescens. Infect., 11, 315-317.

Kopeco, J., \& Cohen, S. N. (1975). Site Specific recA-independent Recombination between Bacterial Plasmid: Involvement of Palindromes at Recombination loci. Proc. Natl. Acad. Sci., 72, 1373-1377.

Kretschmer, P. J., \& Cohen, S. N. (1979). Effect of Temperature on Translocation Frequency of the Tn3 Element. J. Bacteriol., 139, 515-519.

Kumarasinghe, G., Liew, H. Y., \& Chow, C. (1992). Antimicrobial Resistance: Patterns and Trends in the National University Hospital, Singapore (1989-91). Malaysian J. Pathol., 14, 95-103.

Lewin, B. (1990). The Dynamic Genome: DNA in flux. I. "Gene VI" (pp. 623-672). Oxford: Oxford University press.

Li, L., \& Lim, C. K. (2000). A novel Large Plasmid Carrying Multiple Beta-lactam Resistance Genes Isolated from a Klebsiella pneumoniae Strain. J. Microbiol., 88, 1038-1048.

Livermore, D. M. (1987). Clinical Significance of Beta-lactamase Induction and Stable Derepression in Gram-negative Rods. Euro. J. Clin. Microbiol., 6, 439-445. http://dx.doi.org/ 10.1371/journal.ppat.1000353

Livermore, D. M. (1995). $\beta$-lactamases in Laboratory and Clinical Resistance. Clin. Microbiol. Rev., 8, 557-584.

Mahon, C., \& Manuselis, G. (2000). Text Book of diagnostic microbiology (2nd ed). B. Saunders Company.

Marchese, A., Arlet, G., Schito, G. C., Lagrange, P. H., \& Philippon, A. (1996). Detection of SHV-5 Extended-spectrum Beta-lactamase in Klebsiella pneumoniae Strains Isolated in Italy. European Journal of Clinical Microbiol. And Infect. Dis., 15, 245-248.

Matthew, M. (1979). Plasmid Mediated Beta-lactamases of Gram-negative Bacteria: Distribution and Properties. J. Antimicrob. Chemother., 5, 349-358. http://dx.doi.org/ 10.1016/S0140-6736(82)92474-6

Mayer, K. H., Opal, S. M., \& Medeiros, A. A. (1995). Mechanism of Antibiotic Resistance. In G. L. Mandell, J. B. Bennett, \& R. Dolin (Eds.), Mandell, Douglas, and Bennett's principal and practice of infection disease. 
(4th ed.). New York, NY: Churchill Livingstone Inc.

Mc Laughlin, S. (1973). Salicylates and Phospholipids Bilayer Membrane. Nature (London), 243, 243-236.

McClintock, B. (1984). The significance of Responses of the Genome to Challenge. Sci., 226, 792-801.

McMurry, L., Petrucci, R. E., \& Levy S. B. (1980). Active Efflux of Tetracycline Encoded by Four Genetically Different Tetracycline Resistance Determinants in Escherichia coli. Proc. Natl. Acad. Sci., 77, 3974-3977.

Medeiros, A. A. (1993). Nosocomial Outbreaks of Multiresistant Bacteria. Extended-Spectrum Beta-lactamases have Arrived in North America. Ann. Intern. Med., 1119, 428-430.

Meyer, R. J., \& Shapiro, J. A. (1980). Genetic Organization of the Broad-Host Range IncP-1 plasmid R751. J. Bacteriol., 143, 1362-1373. http://dx.doi.org/ 10.1128/JB.183.24.7198-7205.2001

Miller, C., lineElinif, T., Ronen, M., Hanne, I., \& Stanly, N. (2004). SOS Response Induction by $\beta$-lactamase and Bacterial Defense Against Antibiotic Lethality. Sci., 305, 1629-1631.

Moghaddam, M. K. (2001). Co-opertion recombination mechanisms promoting gene clustering and lateral transfer of antibacterial drug resistance ( $\mathrm{Ph}$. D. thesis). ACTA University Upsaliensis.

Montgomerie, J. Z., John, J. F., Atkins, L. M., Gilmore, D. S., \& Ashley, M. A. (1993). Increased Frequency of Large R-plasmids in Klebsiella pneumoniae Colonizing Patients with Spinal Cord Injury. Diagnostic Microbiol. and Infect. Dis., 16, 25-29.

Murmur, J. (1961). A procedure for isolation of Deoxyribo Nucleic Acid from Microorganism. J. Mol. Biol., 3, 208-218.

Nassif, X., Fournier, M., Arondel, J., \& Sansontti, P. J. (1989a). Mucoid Phenotype of Klebsiella pneumoniae is Plasmid Encoded Virulence Factor. Infect. Immun., 57(2), 546-552.

Nikaido, H. (1998). Multiple Antibiotic Resistance and Efflux. Curr. Opin. Microbiol., 1, 516-523.

O'Callaghan, C. H. (1979). Description and Classification of the Newer Cephalosporins and their Relationships with the Established compounds. J. Antimicrob. Chemother., 5, 635-671. http://dx.doi.org/10.1159/000238269)

O'Connell, U. (1984). Genetic Transfer in Prokaryotes: Transformation, Transduction, and Conjugation. In A. Auhler, \& K. Timmis (Eds.), Advanced Molecular Genetics. Berline: Springer Verlage.

Orgel, L. E., Crick, F. H., \& Sapienza, C. (1980). Selfish DNA. Nat., 288, 645-646.

Pansegru, W., Lanka, E., Barth, P. T., Figurski, D. H., Guiney, D. G., Haas, D., ... Thomas, C. M. (1994). Complete Nucleotide Sequence of Birmingham Inc P $\alpha$ plasmid . Compilation and Comparative Analysis. $J$. Mol. Biol., 239, 623-663.

Payne, D. J., \& Amyes, S. G. (1991). Transferable Resistance to Extended-spectrum Beta-lactams: A major Threat or A minor Inconvenience? Journal of Antimicrob. Chemother, 27, 255-261. http://dx.doi.org/10.1093/jac/27.3.255 PMid:203753

Peterson, B. C., Hashimoto, H., \& Rownd, R. H. (1982). Cointegrate Formation Between Homologous Plasmid in Escherichia coli. J. Bacteriol., 151, 1086-1094. http://dx.doi.org/ 10.1007/s11248-009-9246-3

Philippon, A., Redje, S. B., Fournier, G., \& Hassen, A. B. (1989). Epidemiology of Extended-Spectrum $\beta$ -lactamases. Infect., 17, 347-354.

Pospiech, A., \& Neuman, A. (1995). Preparation and Analysis of Genomic and Plasmid DNA. In T. Kieser (Ed.), Genomic DNA Isolation. Norwich, UK: John Innes Center.

Prodiner, W. M., Abaurenfeind, I., Amman, S., \& Fausler, B. (1996). Molecular Epidemiology of Klebsiella Pneumoniae Producing SHV-5 Beta-lactamase: Parallel Out break Due to Multiple of Microbiology. 34(3), 564-568.

Rammelkamp, C. H., \& Maxon, T. (1942). Resistance of Staphylococcus aureus to the Action of Penicillin. Proc. Soc. Exp. Biol. Med., 51, 386-389.

Reed, C. S., Barrett, S. P., Threlfall, E. J., \& Cheasty, T. (1995). Control of Infection with Multiple Antibiotic Resistant Bacteria in A hospital renal unit: the value of plasmid characterization. Epidemiol. and Infect., 115, 61-70.

Reed, R. R. (1981). Resolution of Co integrates Between Transposon $\gamma \delta$ and Tn3 Defines the Recombination Site. Proc. NatI. Acad. Sci., 78, 3428-3432. 
Rubens, C. E., Farrar, W. E., McGee, Z. A., \& Schaffner, W. (1981). Evolution of Plasmid Mediating Resistance to Multiple Antimicrobial Agents During a prolonged epidemic of nosocomial infection. J. Infect. Dis., 143, 170-181.

Rubens, C., Heffron, F., \& Falkow, S. (1976). Transposition of A plasmid Deoxyribonucleic Acid Sequence that Mediates Ampicillin Resistance: Independence from Host rec Function and Orientation of Insertion. Bacteriol., 128, 425-434.

Rusina, O. Y., Mirskaya, E. E., Andreeva, I. V., \& Skavronskaya, A. G. (1992). Precise Excision of Transposons and Point Mutations Induced by Chemicals. Mutat. Res., 283, 161-168.

Sambrook, J., Fritgah, E., \& Maniatis, T. (1989). Molecular Cloning: A laboratory Manual. Cold spring Harbour laboratory, New York.

Sanders, C. C., \& Sanders, W. E. (1992). Beta-Lactam Resistance in Gram-negative Bacteria: Global Trends and Clinical Impact. Clin. Infect. Dis., 15, 824-839.

Sawant, A. A. (2005). Descriptive and Molecular Epidemiology of Antibiotic Resistant gram-negative Enteric Bacteria from Dairy Cattle ( $\mathrm{Ph}$. D. thesis). Pennsylvania State University

Schiappa, D. A., Hayden, M. K., Matushek, M. G., Hashemi, F. N., Sullivan, J., Smith, K. Y., ... Trenholme, G. M. (1996). Ceftazidime resistant Klebsiella pneumoniae and Escherichia coli Blood Stream Infection: A case-control and Molecular Epidemiological Investigation. J. Infect. Dis., 174, 529-536.

Seldon, R., Lee, S., Wang, W. L., Bennett, J. V., \& Eickoff, T. C. (1971). Nosocomial Klebsiella infection: Intestinal Colonization as a Reservoir. Ann Intern Med., 74, 657-664.

Shannon, A., Kevin, B., Paul, S., Xiaoqin, X., Alan, J., Hamish, B., ... Garry, F. (1998). Extended-spectrum Beta lactamase Producing Klebsiella pneumoniae Strain Causing Nosocomial Out break of Infection in United Kingdom. J. clin. Microbiol., 36(10), 3105-3110.

Silhavy, T. J., Berman, M. L, \& Enquist, L. W. (1984). Experiments with Gene Fusion (pp. 183-185). Gold spring Harbor laboratory. New York.

Simoons-Smit, A. M., Verweij-Vanvught, A. M. J., \& Maclaren, D. M. (1984). Virulence of Klebsiella Strain in Experimentally Induced Skin Lesion in the Mouse. J. Med. Microbial., 17, 67-77.

Singleton, P., \& Sainsbury, D. (1993). Transposon. In Dictionary of Microbiology and Molecular Biology. UK: John Wiley \& Sons.

Sirot, D., De Champs, C., Chanal, C., Labia, R., Darfeuille-Michaud, A., Perroux, R., \& Sirot, J. (1991). Translocation of Antibiotic Resistance Determinants Including an Extended-spectrum Beta-lactamase Between Conjugative Plasmids of Klebsiella pneumoniae and Escherichia coli. Antimicrob. and Chemother., 35, 1576-1581.

Spratt, B. G. (1994). Resistance to antibiotics mediated by target alterations. Sci., 264, 388-393.

Thomas, C. M., \& Smith, C. A. (1987). Incompatibility group P plasmid: Genetic, Evolution and Use in Genetic Manipulation. Annu. Rev. Microbiol., 41, 77-101.

Thorsted, D. S., Macartney, D. P., Kostelidou, K., \& Thomas, C. M. (1996). Conservation of the Genetic Switch Between Replicon and Transfer of Inc P Plasmid but Divergence of the Replication Function which are major Host Range Determinants. Plasmid, 36, 95-111.

Thorsted, P. B., Macartney, D. P., Akhtar, P., Haines, A. S., Ali, N., \& Davidson, P. (1998). Complete Sequence of the IncP Beta Plasmid R751: Implications for Evolution and Organization of the IncP Backbone. J. Mol. Biol., 282, 969-990. http://dx.doi.org/10.1006/jmbi.1998.2060

Urban, C., Meyer, K. S., Mariano, N., Rahal, J. J., Flamm, R., Rasmussen, B. A., \& Bush, K. (1994) Identification of TEM-26 Beta-lactamase Responsible for a Major Outbreak of Ceftazidime-Resistant Klebsiella pneumoniae. Antimicrob. and Chemother, 38, 392-395.

Venezia, R. A., Scarano, F. J., Preston, K. E., Steele, L. M., Root, T. P., Limberger, R., ... Kacica, M. A. (1995). Molecular Epidemiology of an SHV-5 Extended-Spectrum Beta-lactamase in Enterobacteriaceae isolated from infants in a neonatal intensive care unit. Clin. Infect. Dis., 21, 915-923.

Wallace, M. R., Johnson, A. P., Daniel, M., Malde, M., \& Yousif, A. A. (1995). Sequential Emergence of Multi-resistant Klebsiella pneumoniae in Bahrain. J. Infect, 31, 247-252. http://dx.doi.org/10.1016/0195-6701(95)90203-1. 
Wang, F., Wang, Y., \& Zhu, D. (1995). Drug Resistant Mechanism of Clinical Isolates of Klebsiella pneumoniae. Chung-Hua I Hsueh Tsa Chih., 75, 60-61.

Weidel, W., \& Pelzer, H. (1964). Bag Shaped Macromolecules- A new outlook on Bacterial Cell Walls. Adv. Enzymol. Relat. Areas Mol. biol., 26, 193-232.

Wessler, S. R. (1996). Turned on by stress. Plant retrotransposon. Curr Biol., 6, 959-961.

Yamanoto, T., Yamagata, S., Hashimoto, Y., \& Yamagishi, S. (1980). Restriction Endonuclease Cleavage Map of the Ampcillin Transposon Tn2601 and Tn2602. Microbiol. Immunol., 24, 1139-1149.

Zajcek, G. (1994). The Antibiotic Paradox Microbial Resistance to Antibiotics and the Wisdom of the Body. The cancer J., 7, 168. 